The death of Ali Salem Lektrik early this year comes as a deep sadness to those in the Society who knew him. $\mathrm{He}$ was a key figure in Cyrenaican archaeology for several decades, and his lively personality will be much missed.

Originally from Shahat, Ali Lektrik owed his surname to the fact that his grandfather was the first person in the village to have electricity. Ali worked as a labourer on Richard Goodchild's excavations in Cyrene. Goodchild recognised his potential and sent him to Britain on an archaeological conservation course. After his return he was appointed Inspector of Antiquities at Tocra in the 1960s, before becoming Deputy Controller of Antiquities for Benghazi. He was instrumental in arranging the excavations of Sidi Khrebish in the 1970s, and even after leaving the Antiquities Service he continued to provide much assistance-and warm hospitality-to British missions working in and around Benghazi, especially to those teams working at Euesperides from

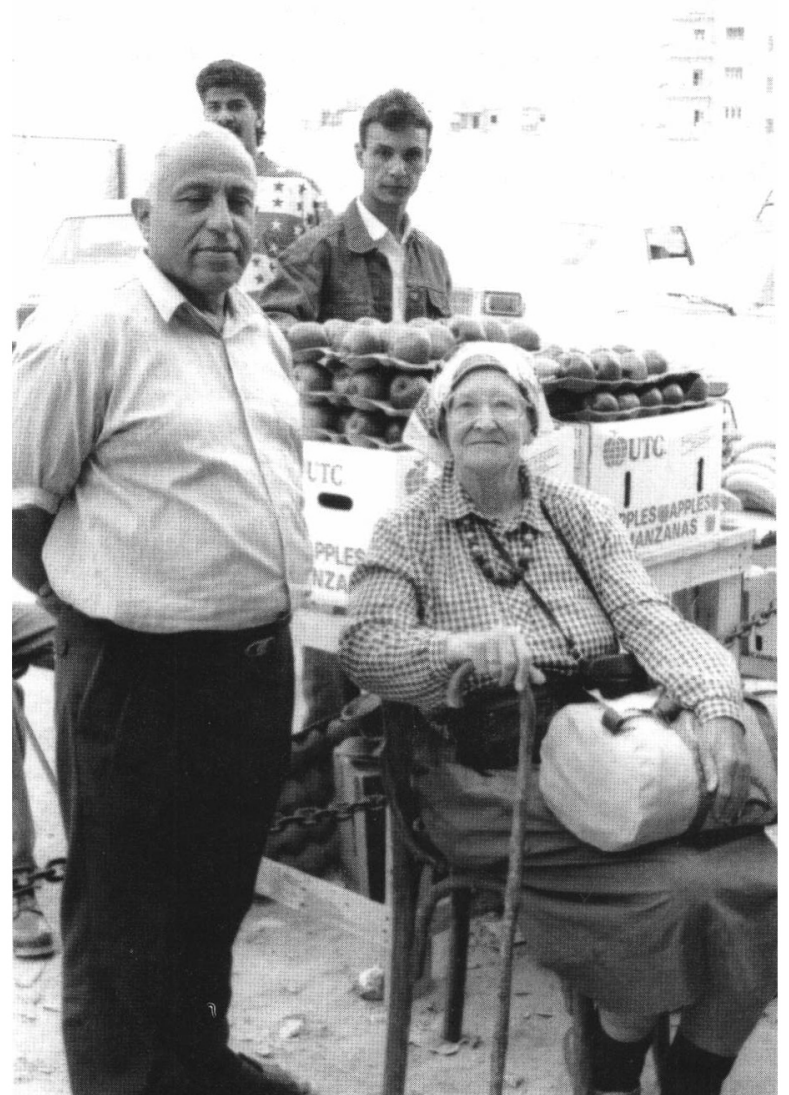

Ali Lektrik (left) with Joyce Reynolds. 1994 until 2001.

\title{
Andrew Wilson
}

Without Ali Salem Lektrik's tireless work influencing the municipality of Benghazi in the autumn of 1971 there would have been no excavations at the site of the Hellenistic and Roman city of Berenice at Sidi Khrebish. Ali managed eventually to persuade the Mayor of Benghazi to reduce the number of lorries fed by a large bulldozer from about thirty, down progressively over some weeks to none, thus saving the site from total destruction.

Shortly after this success, Ali Salem secured a magnificent home for the Benghazi antiquities department in a large Italian building on Omar Muktar Square, a huge improvement on the two-roomed third-floor flat on the outskirts that was overflowing with finds.

This large rest house was the base for the Society of Libyan Studies excavation team during the 1970s. At the time we did not appreciate the huge amount of effort that Ali put in behind the scenes to protect us all from bureaucracy and our own faux pas. He saved days for us on visa renewals, let us use his personal postbox for our mail, and got us out of many scrapes. Perhaps the most memorable was when police apprehended team members for taking photographs in the souk to use up a roll of site film on the way back from a hard day's photography. When Ali turned up at the police station he somehow managed not only to get the camera back, but also the roll of film-intact! 
Ali was a deeply astute diplomat in a very difficult political climate. His explicit strategy was to remain second-in-command. He also advised that when naming children one should play safe and give them religious-based rather than politically-based names. He was a superb networker, with friends everywhere, and he assiduously cultivated friends among Benghazi's doctors and academics.

His next-door neighbour was related to Gaddafi, who had kind words for Ali's daughters when he stayed there. On one occasion in the mid 1970s, faced with a major threat of road building through Greek tombs in Cyrene, Ali asked Gaddafi to intervene. Gaddafi replied it was not their heritage, so why intervene? Ali wisely responded that while Greeks and Romans may have instigated the work, it was Libyan workmen who built the buildings. Unfortunately, shortly afterwards a major internal political crisis put an end to any help from that quarter.

Ali always appeared relaxed, with a smile never far away. He was modest but gently determined, with enormous quiet charm. He always had something good to say about everyone and invariably ended a meeting or a conversation with a joke. He was very generous and hospitable, took pride in inviting excavators and scholars alike to his home, and was keen to communicate Libyan art, culture and humour to us all.

Ali was the driving force, always as nominal second-in-command, in getting the resources to convert the upper floors of the Omar Muktar Square headquarters into a museum, with mosaics mounted on walls and glass cabinets displaying the best of local finds. He took great pains to preserve what he could. For example, he was proud of the little hut he had built over the most complete of the early Roman mosaics at Sidi Khrebish. He remained interested in archaeological conservation, having enjoyed a brief course in that skill at the Institute of Archaeology in London, and encouraged younger Libyans to similarly develop their interests.

So it was a deep personal sadness to Ali that the Antiquities headquarters, rest house and museum were levelled at only a couple of weeks' notice in August 1979 to enlarge Omar Muktar Square for the special parade marking the tenth anniversary of the Libyan Revolution. I was there at this dreadful time and was much impressed with Ali's fortitude and determination, organising his staff to work day and night to dismantle a decade's achievement. He subsequently moved away from the Antiquities service, spending the difficult years of the 1980s and 1990s working with the Daewoo Corporation.

Ali was extremely proud of the work that the Society of Libyan Studies carried out in Benghazi, and the stream of publications and theses that put Benghazi and Cyrenaica at the forefront of Mediterranean archaeological research. He was particularly pleased and helpful with our interest and efforts in the Islamic period too.

The Society, and archaeology in general, owes Ali Salem a huge debt, for without his initiative and dedication in 1971, which I personally witnessed day in day out, our knowledge of Cyrenaican history and archaeology would be immeasurably poorer.

John Riley 